\title{
Cholesteryl Ester Transfer Protein B1B1 Genotype Is Associated with a Parental History of Cardiovascular Diseases in Taiwanese People
}

\author{
Ming-Chia Hsieh ${ }^{a-c}$ Chung-Chi Chen ${ }^{b} \quad$ Jaw-Yuan Wang ${ }^{d}$ Inn-Wen Chong ${ }^{a}$ \\ Chi-Jung Yhe e Shyi-Jang Shin ${ }^{a}$ Shiu-Ru Lin ${ }^{b, c}$ \\ ${ }^{a}$ Department of Internal Medicine, ${ }^{b}$ Graduate Institute of Medicine, ${ }^{c}$ Graduate Institute of Medical Genetics, \\ and ${ }^{d}$ Department of Surgery, Kaohsiung Medical University, and ${ }^{\mathrm{K}}$ Kaohsiung Municipal Hsiao-Kang Hospital, \\ Kaohsiung, Taiwan
}

\section{Key Words}

Cholesteryl ester transfer protein TaqIB polymorphism •

Cholesteryl ester transfer protein B1B1 genotype •

Cardiovascular disease, family history

\begin{abstract}
Objective: To investigate the association between family history of cardiovascular disease (CVD) and cholesteryl ester transfer protein (CETP) TaqIB polymorphism in Taiwanese subjects. Subjects and Methods: In this cross-sectional study, 240 subjects ( 115 men and 125 women) were divided into two groups based on whether or not they had a parental history of CVD. Polymerase chain reaction/restriction fragment length polymorphism was used to analyze the genotype of the subjects for the TaqIB polymorphism of CETP in intron 1. Results: The frequency of the B1B1 genotype was significantly higher in Taiwanese subjects with a family history of CVD than in those without it (31.2 vs. $18.8 \%$, odds ratio $=1.97,95 \%$ confidence interval $=1.084-3.579, p=$ 0.035). Siblings with the B1B1 genotype had lower levels of serum high-density lipoprotein cholesterol (HDL-C) than siblings with either B1B2 (46.7 \pm 11.0 vs. $52.5 \pm 11.1 \mathrm{mg} / \mathrm{dl}$, $\mathrm{p}=0.034$ ) or B2B2 genotypes ( $46.7 \pm 11.0$ vs. $55.2 \pm 9.6 \mathrm{mg} /$ $\mathrm{dl}, \mathrm{p}=0.01)$. Conclusion: CETP TaqIB polymorphism is associated with plasma HDL-C levels. The CETP B1B1 genotype may influence the susceptibility to CVD in Taiwan.
\end{abstract}

Copyright $\odot 2008$ S. Karger AG, Basel
(C) 2008 S. Karger AG, Basel

$1011-7571 / 08 / 0172-0143 \$ 24.50 / 0$

Fax +4161306 1234

E-Mail karger@karger.ch

www.karger.com
Accessible online at:

www.karger.com/mpp

\section{Introduction}

Cardiovascular disease (CVD), which includes coronary heart disease (CHD), cerebrovascular disease, and peripheral artery disease, is a major cause of death and disability in both developed and developing countries [1]. There are two general approaches to primary prevention of CVD: population-wide health promotion and targeted intervention of high-risk groups [2-4]. The two approaches are strategically very different, but Hunt et al. [5] have proposed that the use of family history might serve as a unifying theme bridging the two approaches and helping to resolve many of the objections to each. Family history of CVD is the sum of genetic, environmental and common lifestyle factors that may be shared among family members. Knowledge of this information may help establish the risk for CVD. After correcting for measurable familial risk factors such as cholesterol, hypertension, obesity and diabetes, family history remains an independent risk factor for CVD [6-9]. Therefore, interpretation of family history information might be the most appropriate screening approach to the identification of individuals susceptible to CVD.

The human genome project has increased the possibility of using specific genes to assess disease risk and identify high-risk subgroups [10]. In fact, recent advances in cardiovascular genetics have highlighted interaction between common genetic variants and CVD [11]. 
Plasma high-density lipoprotein cholesterol (HDL-C) level is widely recognized as a powerful predictor for the development of coronary artery disease $[12,13]$. Cholesteryl ester transfer protein (CETP) is a protein that plays a central role in HDL-C metabolism. CETP can modify the lipid composition of plasma by transferring triglycerides and cholesterol esters between lipoproteins $[14,15]$. Recent studies have found CETP inhibitors to markedly increase HDL-C in individuals with low HDL-C levels $[16,17]$. Several polymorphisms have been found in the CETP gene locus [18-20]. The most studied polymorphism to date, TaqIB, has been shown to be a silent base change affecting the 227th nucleotide in the first intron of the gene [21]. The B2 allele of this polymorphism has been associated with increased HDL-C levels [22, 23]. Recently, Elosua et al. [24] evaluated the association of 12 variants in 10 lipoprotein-related genes with carotid intimal medial thickness and found that, in men, only the CETP TaqIB polymorphism could be associated with carotid intimal medial thickness. Ordovas et al. [25] reported that the CETP TaqIB genotype played a significant role in determining HDL-C variability and this association translated into a lower CHD risk in men but not in women. Still, while many studies have been done to investigate the relationship between the TaqIB genotype and the risk of CVD, the results have not been consistent [26-29]. Since no study of CETP TaqIB gene polymorphism and the risk of CVD has been performed in Taiwan, we wanted to investigate the association between family history of CVD and CETP TaqIB gene polymorphism in people of Han Chinese descent in Taiwan.

\section{Subjects and Methods}

\section{Subjects}

Between May 2003 and March 2004, a total of 240 Taiwanese subjects (115 men and 125 women) were recruited at the Kaohsiung Municipal Hsiao-Kang Hospital. Exclusion criteria were: (a) a previous diagnosis of acute myocardial infarction and/or cerebrovascular disease; (b) a definite history of angina pectoris with documented electrocardiographic findings and specific therapy including sublingual nitroglycerine, coronary vasodilators or antiplatelet agents; (c) placement of coronary stents, percutaneous transluminal coronary angioplasty, coronary artery bypass graft; positive results after a coronary angiography examination, a treadmill test or a radionuclide myocardial perfusion test; (d) electrocardiogram abnormalities from a 12-lead resting electrocardiogram [Minnesota codes 1.1-1.2 (large Q and QS waves), 1.3 (small Q and QS waves), 4.1-4.4 (ST-T depression), 5.1-5.3 (flattened or inverted T waves) or 7.1.1 (complete left bundle branch block)] [30], a positive Rose questionnaire for angina or prolonged chest pain [31]; (e) diabetes; or (f) hypertension.
The hospital's Human Research Ethics Committee approved the design of this study, and informed consent was obtained from each participant. Individual interviews were held with participants about their disease and smoking history. They received a complete physical examination. Routine blood analyses were performed. Measurements were taken to calculate the body mass in$\operatorname{dex}(\mathrm{BMI})$.

The 240 subjects were divided into two groups based on their family history of CVD: group 1 consisted of 112 subjects with a family history of CVD (57 coronary artery disease and 55 strokes) and group 2 consisted of 128 subjects with no family history of CVD. An individual was considered to have a family history of CVD when he or she reported having a parent(s) with CVD before the age of 55 years.

The information regarding an individual's family history of CVD was obtained from both hospital records and a questionnaire completed by the subject and confirmed verbally by interviewing the subject's parent(s). Individuals with an unclear or unknown family history of CVD were excluded.

\section{Biochemical Analyses}

Total cholesterol and triglyceride (TG) were determined by a Beckman Coulter biochemical analyzer (Synchron CX-5CE, Fullerton, Calif., USA). The total cholesterol and TG levels were analyzed by the cholesterol oxidase/peroxidase method and the lipase/glucose oxidase/peroxidase method (Beckman reagent kit, Fullerton, Calif., USA), respectively. The HDL-C and low-density lipoprotein cholesterol (LDL-C) fractions were determined with an electrophoresis analyzer (Helena REP). The Helena REP electrophoresis system separates very-low-density lipoprotein (VLDL), HDL-C and LDL-C by agarose gel electrophoresis [32]. In our study, the specimen was applied to an agarose gel. The lipoprotein fractions were separated by electrophoresis and stained with Fat Red 7B. The stained bands were quantified with a scanning densitometer (rapid electrophoresis analyzer) using a 525$\mathrm{nm}$ filter. The control was used as a marker for the location of the lipid bands and was quantified to verify the accuracy of the measurements of lipoprotein fractions.

\section{Detection of CETP TaqIB Genotypes}

CETP TaqIB genotypes were determined by polymerase chain reaction (PCR) amplification of genomic DNA, followed by restriction enzyme digestion. Genomic DNA was extracted from peripheral blood leukocytes with either a QIAamp mini kit (Qiagen) or a Generation Capture Column kit (Gentra Systems). A 535-bp fragment in intron 1 of the CETP gene was PCR amplified with the following oligonucleotide primers: 5'-CACTAGCCCAGAGAGAGAGGAGTGCC-3' (forward) and 5'-CTGAGCCCAGCCGCACACTAAC-3' (reverse) [33]. In PCR cycling, one denaturation cycle $\left(94^{\circ} \mathrm{C}\right.$ for $\left.5 \mathrm{~min}\right)$ was followed by 35 cycles $(94$, 60 , and $72^{\circ} \mathrm{C}$ for $\left.30 \mathrm{~s} \mathrm{each}\right)$. The PCR products were then digested with TaqI restriction endonuclease (GIBCO-BRL; $65^{\circ} \mathrm{C}$ for $2 \mathrm{~h}$ ) and the fragments were separated by electrophoresis in a $2 \%$ agarose gel. The resulting DNA fragments were 174 and 361 bp for the $\mathrm{B} 1$ allele, and $535 \mathrm{bp}$ for the undigested B2 allele.

Statistical Analysis

The clinical and biochemical features of the population are presented as mean $\pm \mathrm{SD}$, median (interquartile range), or percentages. Because the distributions of TG were highly skewed, 
Table 1. Clinical characteristics of subjects with (group 1) and without (group 2) a family history of CVD

\begin{tabular}{lcc}
\hline & $\begin{array}{c}\text { Group 1 } \\
(\mathrm{n}=112)\end{array}$ & $\begin{array}{c}\text { Group 2 } \\
(\mathrm{n}=128)\end{array}$ \\
\hline Sex $(\mathrm{M} / \mathrm{F})$ & $53 / 59$ & $62 / 66$ \\
Age, years & $49.2 \pm 11.0$ & $52.1 \pm 17.2$ \\
BMI & $25.3 \pm 3.9$ & $27.0 \pm 9.5$ \\
Waist, cm & $78.8 \pm 10.2$ & $80.7 \pm 10.0$ \\
Fasting sugar, mg/dl & $91.2 \pm 10.7$ & $89.3 \pm 9.7$ \\
SBP, mm Hg & $122.4 \pm 9.4$ & $123.3 \pm 15.8$ \\
DBP, mm Hg & $78.9 \pm 7.7$ & $77.8 \pm 10.4$ \\
Chol, mg/dl & $192.9 \pm 27.7$ & $190.2 \pm 24.0$ \\
TG, mg/dl & $103(78-187)$ & $102(74-182)$ \\
HDL-C, mg/dl & $52.9 \pm 11.1$ & $53.5 \pm 11.8$ \\
LDL-C, mg/dl & $121.3 \pm 28.1$ & $116.9 \pm 25.1$ \\
Smoking, \% & 19.6 & 19.5 \\
\hline
\end{tabular}

$\mathrm{SBP}=$ Systolic blood pressure; $\mathrm{DBP}=$ diastolic blood pressure; Chol $=$ cholesterol. Results are means \pm SD unless noted otherwise.

${ }^{1}$ Median with interquartile range $(\mathrm{Q} 1-\mathrm{Q} 3)$ in parentheses.

these variables were natural log-transformed for all other analyses. Odds ratios and 95\% confidence intervals were determined to assess the level of differences in distributions for allelic and genotype frequencies between the two groups. The observed frequencies of the genotypes were compared with the frequencies under Hardy-Weinberg equilibrium by $\chi^{2}$ tests [34]. The t test and oneway ANOVA were used to detect the mean differences between the biochemical data and in groups or CEPT genotype. All p values were calculated based on two-sided tests. Significance was defined as $\mathrm{p}$ value less than 0.05 .

\section{Results}

The clinical characteristics of all subjects are listed in table 1. There were no significant differences between groups 1 and 2 with regard to age, BMI, waist circumference, blood pressures, fasting plasma glucose levels, serum cholesterol, TG, HDL-C or LDL-C and the frequency of smoking. Genotype distribution and allele frequencies were in Hardy-Weinberg equilibrium and were comparable between the two groups. The CETP TaqIB genotype was determined unequivocally in all of them. The CETP TaqIB genotype and allele frequencies in both groups are shown in table 2. The CETP B1B1 genotype occurred more frequently in group 1 (31.2\%) than group 2 (18.8\%). Individuals having the CETP B1B1 genotype were associated with having a family history of CVD (group 1; odds ratio $=1.970$, $95 \%$ confidence interval $=1.084-3.579, \mathrm{p}=0.035)$.

CETP B1B1 Genotype Associated with a Parental History of CVD
Table 2. CETP genotype distribution and allele frequency

\begin{tabular}{ccc}
\hline Genotype & Group 1 $(\mathrm{n}=112)$ & Group 2 $(\mathrm{n}=128)$ \\
\hline $\begin{array}{c}\text { Genotypes } \\
\text { B1B1 }\end{array}$ & & \\
B1B2 & $35(31.2)$ & $24(18.8)$ \\
B2B2 & $60(53.6)$ & $72(56.2)$ \\
Alleles & $17(15.2)$ & $32(25.0)$ \\
B1 & & \\
B2 & $130(58)$ & $120(46.9)$ \\
& $94(42)$ & $136(53.1)$
\end{tabular}

Figures in parentheses are percentages.

${ }^{\text {a }}$ Odds ratio $=1.970,95 \%$ confidence interval $=1.084-3.579$, $\mathrm{p}=0.035$.

Table 3. Clinical characteristics of subjects according to CETP genotype

\begin{tabular}{|c|c|c|c|}
\hline & \multicolumn{3}{|l|}{ Genotype } \\
\hline & B1B1 & B1B2 & B2B2 \\
\hline Number of subjects & 59 & 132 & 49 \\
\hline Age, years & $50.2 \pm 11.6$ & $51.2 \pm 13.0$ & $51.8 \pm 13.1$ \\
\hline BMI & $26.7 \pm 4.3$ & $26.1 \pm 3.4$ & $26.2 \pm 4.0$ \\
\hline Waist, $\mathrm{cm}$ & $80.2 \pm 9.9$ & $79.3 \pm 10.6$ & $79.0 \pm 9.8$ \\
\hline Fasting sugar, mg/dl & $92.0 \pm 12.7$ & $89.1 \pm 10.7$ & $91.3 \pm 14.0$ \\
\hline $\mathrm{SBP}, \mathrm{mm} \mathrm{Hg}$ & $123.1 \pm 11.0$ & $122.6 \pm 15.4$ & $122.8 \pm 18.5$ \\
\hline $\mathrm{DBP}, \mathrm{mm} \mathrm{Hg}$ & $79.3 \pm 10.0$ & $78.1 \pm 10.2$ & $79.0 \pm 12.1$ \\
\hline Chol, mg/dl & $192.8 \pm 22.1$ & $191.7 \pm 28.3$ & $189.2 \pm 23.2$ \\
\hline $\mathrm{HDL}^{-\mathrm{C}^{1}}, \mathrm{mg} / \mathrm{dl}$ & $46.7 \pm 11.0$ & $52.5 \pm 11.1$ & $55.2 \pm 9.6$ \\
\hline LDL-C, mg/dl & $120.3 \pm 24.1$ & $118.2 \pm 25.2$ & $119.4 \pm 18.3$ \\
\hline $\mathrm{TG}^{2}, \mathrm{mg} / \mathrm{dl}$ & $106(79-190)$ & $102(72-180)$ & $96(69-176)$ \\
\hline Smoking, \% & 18.6 & 19.7 & 20.4 \\
\hline
\end{tabular}

Data are means \pm SD unless noted otherwise. SBP $=$ Systolic blood pressure; $\mathrm{DBP}=$ diastolic blood pressure; $\mathrm{Chol}=$ cholesterol.

${ }^{1} \mathrm{~B} 1 \mathrm{~B} 1$ vs. $\mathrm{B} 1 \mathrm{~B} 2, \mathrm{p}=0.034 ; \mathrm{B} 1 \mathrm{~B} 1$ vs. $\mathrm{B} 2 \mathrm{~B} 2, \mathrm{p}=0.010$.

${ }^{2}$ Median with interquartile range (Q1-Q3) in parentheses.

The characteristics of the subjects categorized by CETP genotype are shown in table 3. There were no significant differences with respect to age, BMI, waist circumference, blood pressures, blood levels of cholesterol, LDL-C, TG and the frequency of smoking. The CETP genotypes were found to be significantly associated with HDL levels using ANOVA. After a multiple comparison test (Bonferroni), siblings with the B1B1 genotype had lower serum HDL-C than siblings with B1B2 (46.7 \pm 11.0 vs. $52.5 \pm 11.1 \mathrm{mg} / \mathrm{dl}, \mathrm{p}=0.034)$ and $\mathrm{B} 2 \mathrm{~B} 2$ genotypes $(46.7 \pm 11.0$ vs. $55.2 \pm 9.6 \mathrm{mg} / \mathrm{dl}, \mathrm{p}=0.01)$. 


\section{Discussion}

CVDs make up some of the major causes of mortality and disabilities in the world. Although screening for traditional risk factors (e.g. elevated blood pressure, plasma glucose and lipids) has been shown to identify persons at increased risks for CVD, most CVD events occur to persons with risk factor measurements in the middle of the distribution rather than at the extremes. Therefore, the cost-effectiveness of screening the populations to identify persons with abnormal traditional risk factors has been questioned [35]. Meanwhile, family history of CVD remains an independent risk factor for CVD even after correcting for traditional risk factors for CVD and has been used in previous studies $[36,37]$. Family history of CVD does not always connote genetic susceptibility, but it is the most effective, efficient and low-cost way of identifying subgroups at risk for CVD in the population as evidenced by the new guidelines for primary prevention of CHD and stroke issued by the American Heart Association [38]. Using family history we were able to identify individuals at high risk for CVD and our data revealed that the frequency of the B1B1 genotype of CETP is significantly higher in Taiwanese subjects with a family history of CVD than in those without. CVDs were more common among parents of homozygous B1 carriers than among parents of homozygous B2 carriers, suggesting that the $\mathrm{B} 1$ allele was transmitted from the parent with CVD to the child. Many studies investigated the relationship between the TaqIB genotype and the risk of CVD, but their results have been inconsistent [26-29]. Recently, we found that the presence of the CETP B1B1 genotype could predict coronary artery disease in Taiwanese subjects with type 2 diabetes [39]. In this study, our results suggest that the CETP TaqIB polymorphism might play some role in CVD of Taiwanese people. Further study is necessary to confirm whether or not it does.

In this study, CETP TaqIB gene polymorphism is associated with serum HDL-C levels. This finding is con- sistent with the results of previous studies [25, 40, 41]. Although other factors such as sex, smoking and BMI have been reported to be associated with CETP genotype $[42,43]$, there was no such association here.

How CETP isoforms might influence the development of CVD is unclear. CETP may mediate cholesterol redistribution by reducing the amount of cholesterol ester extracted from atherosclerotic lesions as a result of reduced HDL function. However, CETP regulates one of the steps in reverse cholesterol transport, an anti-atherogenic process. CETP is involved in modulating the concentration of HDL $[44,45]$ and may, therefore, alter susceptibility to CVD. Since the CETP TaqIB polymorphism is located in an intron, it may not be a functional mutation. The results of the present study show that the CETP TaqIB polymorphism can be related with a family history of CVD and HDL-C levels. Further studies are needed to determine if this polymorphism is a nonfunctional marker in linkage disequilibrium with functional variants of the CETP gene or other closely linked genes.

There are limitations inherent in the design of this study. This is a cross-sectional study. The effect of CETP genotype with plasma CETP levels was not determined because plasma samples that had not been freeze-thawed were unavailable. However, the association between CETP TaqIB genotype and CETP levels has previously been investigated in many studies [22-25], although with conflicting results. These inconsistencies may be a result of differences among study samples or differences among the complex CETP activity assays that were used.

\section{Conclusion}

Family history of CVD was used to identify individuals at high risk for CVD. Our results show that the CETP B1B1 genotype may influence the susceptibility to CVD in Taiwan, as parents of offspring with the B1B1 genotype reported an increased prevalence of CVD.

\section{References}

1 Stajszczyk M, Gminski J: The role of DNA polymorphism in the renin-angiotensin system and the pathogenesis of cardiovascular diseases. Postepy Hig Med Dosw 1997;51: 171-183.

2 Expert Committee on Prevention of Coronary Heart Disease: Prevention of Coronary Heart Disease. Geneva, World Health Organization, 1982.
Oliver MF: Should we not forget about mass control of coronary risk factors? Lancet 1983;ii:37-38.

4 Kottke TE, Puska P, Salonen JT, Tuomilehto J, Nissinen A: Projected effects of high-risk versus population-based prevention strategies in coronary heart disease. Am J Epidemiol 1985;121:697-704.

\footnotetext{
5 Hunt SC, Gwinn M, Adams TD: Family history assessment: strategies for prevention of cardiovascular disease. Am J Prev Med 2003; 24:136-142.

-6 Hopkins PN, Williams RR, Kuida H, Stults BM, Hunt SC, Barlow GK, Ash KO: Family history as an independent risk factor for incident coronary artery disease in a high-risk cohort in Utah. Am J Cardiol 1988;62:703-707.
} 
7 Jorde LB, Williams RR: Relation between family history of coronary artery disease and coronary risk variables. Am J Cardiol 1988; 62:708-713.

$\checkmark 8$ Myers RH, Kiely DK, Cupples LA, Kannel WB: Parental history is an independent risk factor for coronary artery disease: the Framingham Study. Am Heart J 1990;120:963969.

-9 Liao D, Myers R, Hunt S, Shahar E, Paton C, Burke G, Province M, Heiss G: Familial history of stroke and stroke risk. The Family Heart Study. Stroke 1997;28:1908-1912.

10 Collins FS, McKusick VA: Implications of the human genome project for medical science. JAMA 2001;285:540-544.

11 Nabel EG: Cardiovascular disease. N Engl J Med 2003;49:60-72.

12 Gordon DJ, Rifkind BM: High-density lipoprotein: the clinical implications of recent studies. N Engl J Med 1989;321:1311-1316.

-13 Stampfer MJ, Sacks FM, Salvini S, Willett WC, Hennekens $\mathrm{CH}$ : A prospective study of cholesterol, apolipoproteins, and the risk of myocardial infarction. N Engl J Med 1991; 325:373-381.

-14 Tall A: Plasma lipid transfer proteins. Ann Rev Biochem 1995;64:235-257.

-15 Hannuksela ML, Liinamaa MJ, Kesaniemi YA: Relation of polymorphisms in the cholesteryl ester transfer protein gene to transfer protein activity and plasma lipoprotein levels in alcohol drinkers. Atherosclerosis 1994; 110:35-44.

16 Davidson MH, McKenney JM, Shear CL, Revkin JH: Efficacy and safety of torcetrapib, a novel cholesteryl ester transfer protein inhibitor, in individuals with below-average high-density lipoprotein cholesterol levels. J Am Coll Cardiol 2006;48:1774-1781.

$\checkmark 17$ Brousseau ME, Schaefer EJ, Wolfe ML, Bloedon LT, Digenio AG, Clark RW, Mancuso JP, Rader DJ: Effects of an inhibitor of cholesteryl ester transfer protein on HDL cholesterol. N Eng J Med 2004;350:1505-1515.

$\checkmark 18$ Kondo I, Berg K, Drayna D, Lawn R: DNA polymorphism at the locus for human cholesteryl ester transfer protein (CETP) is associated with high density lipoprotein cholesterol and apolipoprotein levels. Clin Genet 1989;35:49-56.

$\checkmark 19$ Freeman DJ, Griffin BA, Holmes AP, Lindsay GM, Gaffney D: Polymorphisms in the gene coding for cholesteryl ester transfer protein are related to plasma high density lipoprotein cholesterol and transfer protein activity. Clin Sci 1990;79:575-581.

-20 Ordovas JM, Cupples LA, Corella D, Otvos JD, Osgood D, Martinez A, Lahoz C, Coltell O, Wilson PW, Schaefer EJ: Associations of cholesteryl ester transfer protein-TaqIB polymorphism with variations in lipoprotein subclasses and coronary heart disease risk: the Framingham study. Arterioscler Thromb Vasc Biol 2000;20:1323-1329.
21 Drayna D, Lawn R: Multiple RFLPs at the human cholesteryl ester transfer protein (CETP) locus. Nucleic Acids Res 1987;15: 4698.

22 Freeman DJ, Griffin BA, Holmes AP, Lindsay GM, Gaffney D, Packard CJ, Shepherd J: Regulation of plasma HDL cholesterol and subfraction distribution by genetic and environmental factors. Associations between the TaqI B RFLP in the CETP gene and smoking and obesity. Arterioscler Thromb 1994;14: 336-344.

23 Kuivenhoven JA, de Knijff P, Boer JM, Smalheer HA, Botma GJ, Seidell JC, Kastelein JJ, Pritchard PH: Heterogeneity at the CETP gene locus. Influence on plasma CETP concentrations and HDL cholesterol levels. Arterioscler Thromb Vasc Biol 1997;17:560568.

24 Elosua R, Cupples LA, Fox CS, Polak JF, D’Aqostino RA, Wolf PA, O’Donnell CJ, Ordovas JM: Association between well-characterized lipoprotein-related genetic variants and carotid intimal medial thickness and stenosis: the Framingham Heart Study. Atherosclerosis 2006;189:222-228.

25 Ordovas JM, Cupples LA, Corella D, Otvos JD, Osqood D, Martinez A, Lahoz C, Coltell O, Wilson PW, Schaefer EJ: Association of cholesteryl ester transfer protein-TaqIB polymorphism with variations in lipoprotein subclasses and coronary heart disease risk: the Framingham study. Arterioscler Thromb Vasc Biol 2000;20:1323-1329.

26 Arca M, Montali A, Ombres D, Battiloro E, Campagna F, Ricci G, Verna R: Lack of association of the common TaqIB polymorphism in the cholesteryl ester transfer protein gene with angiographically assessed coronary atherosclerosis. Clin Genet 2001; 60:374-380.

27 Liu S, Schmitz C, Stampfer MJ, Sacks FM, Hennekens CH, Lindpaintner K, Ridker PM: A prospective study of TaqIB polymorphism in the gene coding for cholesteryl ester transfer protein and risk of myocardial infarction in middle-aged men. Atherosclerosis 2002; 161:469-474

28 Talmud PJ, Hawe E, Robertson K, Miller GJ, Miller NE, Humphries SE: Genetic and environmental determinants of plasma high density lipoprotein cholesterol and apolipoprotein AI concentrations in healthy middle-aged men. Ann Hum Genet 2002;66: 111-124.

29 Eiriksdottir G, Bolla MK, Thorsson B, Sigurdsson G, Humphries SE, Gudnason V: The $629 \rightarrow \mathrm{A}$ polymorphism in the CETP gene does not explain the association of the TaqIB polymorphism with risk and age of myocardial infarction in Icelandic men. Atherosclerosis 2001;159:187-192.
30 Scheidt-Nave C, Barrett-Connor E, Wingard DL: Resting electrocardiographic abnormalities suggestive of asymptomatic ischemic heart disease associated with non-insulindependent diabetes mellitus in a defined population. Circulation 1990;81:899-906.

31 Rose GA, Blackburn H, Gillurn RF, Prineas RJ: Cardiovascular Survey Methods, ed 2. Geneva, World Health Organization, 1982.

32 Contois J, Gillmor R, Moore R, Contois L, Macer J, Wu A: Quantitative determination of cholesterol in lipoprotein fractions by electrophoresis. Clin Chim Acta 1999;282: 1-14.

33 Fumeron F, Betoulle D, Luc G, Behaque I, Ricard S, Poirier O, Jemaa R, Evans A, Arveiler D, Marques-Vidal P, Bard JM, Fruchart JC, Ducimetieve P, Apfelbaum M, Cambien F: Alcohol intake modulates the effect of a polymorphism of the cholesteryl ester transfer protein gene on plasma high density lipoprotein and the risk of myocardial infarction. J Clin Invest 1995;96:1664-1671.

34 Cannings C, Edwards AW: Expected genotypic frequencies in a small sample: deviation from Hardy-Weinberg equilibrium. Am J Hum Genet 1969;21:245-247.

35 Kottke TE, Puska P, Salonen JT, Tuomilehto J, Nissinen A: Projected effects of high-risk versus population-based prevention strategies in coronary heart disease. Am J Epidemiol 1985;121:697-704.

36 Hunt SC, Williams RR, Barlow GK: A comparison of positive family history definitions for defining risk of future disease. J Chronic Dis 1986;39:809-821.

37 Scheuner MT, Wang SJ, Raffel LJ, Larabell SK, Rotter JI: Family history: a comprehensive genetic risk assessment method for the chronic conditions of adulthood. Am J Med Genet 1997;71:315-324.

38 Pearson TA, Blair SN, Daniels SR, Eckel RH, Fair JM, Fortmann SP, Franklin BA, Goldstein LB, Greenland P, Grundy SM, Hong Y, Miller NH, Lauer RM, Ockene IS, Sacco RL, Sallis JF, Smith SC, Stone NJ, Taubert KA: AHA Guidelines for primary prevention of cardiovascular disease and stroke: 2002 update: consensus panel guide to comprehensive risk reduction for adult patients without coronary or other atherosclerotic vascular diseases. Circulation 2002;106:388-391.

-39 Hsieh MC, Tien KJ, Chang SJ, Lo CS, Hsin SC, Hsiao JY, Hsu SC, Liang HT, Chen HC, Shin SJ, Lin SR: Cholesteryl ester transfer protein B1B2 genotype as a predictor of coronary artery disease in Taiwanese with type 2 diabetes mellitus. Metabolism 2007;56:745750 .

40 Hsu LA, Ko YL, Hsu KH, Ko YH, Lee YS: Genetic variations in the cholesteryl ester transfer protein gene and high density lipoprotein cholesteryl levels in Taiwanese Chinese. Hum Genet 2002;110:57-63. 
41 Boekholdt SM, Sacks FM, Jukema JW, Shepherd J, Freeman DJ, McMahon AD, Cambien F, Nicaud V, Grooth GJ, Talmud PJ, Humphries SE, Miller GJ, Eiriksdottir G, Gudnason V, Kauma H, Kakko S, Savolainen MJ, Arca M, Montali A, Liu S, Lanz HJ, Zwinderman AH, Kuivenhoven JA, Kastelein JJP: Cholesteryl ester transfer protein TaqIB variant, high-density lipoprotein cholesteryl levels, cardiovascular risk, and efficacy of pravastatin treatment. Individual patient meta-analysis of 13,677 subjects. Circulation 2005;111:278-287.
42 Kuivenhoven JA, Jukema JW, Zwinderman AH, de Kniff P, McPherson R, Bruschke AV, Lie KI, Kastelein JJ: The role of a common variant of the cholesteryl ester transfer protein gene in the progression of coronary atherosclerosis. The Regression Growth Evaluation Statin Study Group. N Engl J Med 1998; 338:86-93.

43 Blankenberg S, Rupprecht HJ, Bickel C, Jiang XC, Poirier O, Lackner KJ, Meyer J, Cambien F, Tiret L: Common genetic variation of the cholesteryl ester transfer protein gene strongly predicts future cardiovascular death in patients with coronary artery disease. J Am Coll Cardiol 2003;41:1983-1989.
44 Inazu A, Brown ML, Hesler CB, Agellon LB, Koizumi J, Takata K, Maruhama Y, Mabuchi H, Tall AR: Increased high-density lipoprotein levels caused by a common cholesterylester transfer protein gene mutation. N Engl J Med 1990;323:1234-1238.

45 Inazu A, Jiang XC, Haraki T, Yagi K, Kamon N, Koizumi J, Mabuchi H, Takeda R, Takata K, Moriyama Y: Genetic cholesteryl ester transfer protein deficiency caused by two prevalent mutations as a major determinant of increased levels of high density lipoprotein cholesterol. J Clin Invest 1994;94:18721882 . 